\title{
Intracranial intraparenchymal schwannomas: a series of eight cases
}

\author{
M C Sharma, A K Karak, S B Gaikwad, A K Mahapatra, V S Mehta, K Sudha
}

\begin{abstract}
Intraparenchymal schwannomas of the CNS are extremely rare. Between 1979 and 1993400 cases of intracranial schwannomas were operated on and among them were eight patients with intraparenchymal schwannomas comprising $2 \%$ of intracranial benign nerve sheath tumours. Four of them were located in the cerebral hemispheres and two each in the brain stem and in the cerebellum. In two cases, there was associated neurofibromatosis (NF-1 and NF-2, one case each). The age ranged from 6 months to 45 years with a male/female ratio of 3:1 and, surprisingly, six of them were in the left cerebral or cerebellar hemisphere.
\end{abstract}

(F Neurol Neurosurg Psychiatry 1996;60:200-203)

Keywords: intraparenchymal schwannomas
Intraparenchymal schwannomas of the CNS are extremely rare, although intracranial schwannomas account for up to $8 \%$ of all primary brain tumours. ${ }^{1}$ In a survey of the medical literature, we found a total of 33 cases of intracranial intraparenchymatous schwannomas, mostly in the form of case reports. ${ }^{23}$ The lesion is usually solitary and in only two cases, ${ }^{45}$ an associated neurofibromatosis (NF) was found. We present a series of eight cases of intracranial intraparenchymal schwannomas, including two already reported ${ }^{6 /}$ from our institution. To the best of our knowledge this is the largest series in the medical literature.

\section{Materials and methods}

From 1979 to 1993 we encountered 400 histologically established cases of intracranial schwannomas, of which only eight were intraparenchymal. Four were located in the left cerebral hemisphere, two in the left cerebellar

Table 1 Details of eight patients with intracranial intraparenchymal schwannomas

\begin{tabular}{|c|c|c|c|c|c|c|}
\hline $\begin{array}{l}\text { Patient } \\
\text { no }\end{array}$ & $\begin{array}{l}\text { Age/ } \\
\text { sex }\end{array}$ & $\begin{array}{l}\text { Clinical } \\
\text { features }\end{array}$ & Site & $\begin{array}{l}\text { Duration } \\
\text { of symptoms } \\
\text { of disease }\end{array}$ & $\begin{array}{l}\text { Nouro- } \\
\text { fibroma- } \\
\text { tosis }\end{array}$ & $\begin{array}{l}\text { Radiological } \\
\text { features }\end{array}$ \\
\hline 1 & $19 / \mathrm{F}$ & $\begin{array}{l}\text { Right upper and lower } \\
\text { limb weakness, } \\
\text { abnormal behaviour }\end{array}$ & $\begin{array}{l}\text { Left } \\
\text { occipital } \\
\text { lobe }\end{array}$ & 2.5 months & $\mathrm{NF}-1$ & $\begin{array}{l}\text { Mixed density } \\
\text { mass }\end{array}$ \\
\hline 2 & $8 / \mathrm{M}$ & $\begin{array}{l}\text { Right partial pari- } \\
\text { etal seizures with } \\
\text { generalisation }\end{array}$ & $\begin{array}{l}\text { Left } \\
\text { temporal } \\
\text { lobe }\end{array}$ & 4 years & - & $\begin{array}{l}\text { High } \\
\text { density } \\
\text { mass }\end{array}$ \\
\hline 3 & $6 \mathrm{~m} / \mathrm{F}$ & $\begin{array}{l}\text { Right hemiparesis, } \\
\text { vomiting, generalised } \\
\text { seizures }\end{array}$ & $\begin{array}{l}\text { Left } \\
\text { temporal } \\
\text { lobe }\end{array}$ & 2 months & - & $\begin{array}{l}\text { Mixed } \\
\text { density } \\
\text { mass }\end{array}$ \\
\hline 4 & $21 / M$ & $\begin{array}{l}\text { Headache, } \\
\text { vomiting, } \\
\text { generalised } \\
\text { seizures }\end{array}$ & $\begin{array}{l}\text { Left } \\
\text { frontal } \\
\text { lobe }\end{array}$ & 5 years & $\mathrm{NF}-2$ & $\begin{array}{l}\text { Mixed } \\
\text { density } \\
\text { mass }\end{array}$ \\
\hline 5 & $14 / M$ & $\begin{array}{l}\text { Unsteadiness of } \\
\text { gait, } \\
\text { decreased vision } \\
\text { both eyes, } \\
\text { abnormal behaviour }\end{array}$ & $\begin{array}{l}\text { Brain } \\
\text { stem }\end{array}$ & 1 year & - & $\begin{array}{l}\text { Enhancing } \\
\text { mass in } \\
\text { right } \\
\text { lower } \\
\text { medulla }\end{array}$ \\
\hline 6 & $45 / M$ & $\begin{array}{l}\text { Headache, vomiting, } \\
\text { difficulty in } \\
\text { walking, and speech } \\
\text { slurring }\end{array}$ & $\begin{array}{l}\text { Left } \\
\quad \text { cerebellar }\end{array}$ & 9 months & - & $\begin{array}{l}\text { Low density mass } \\
\text { left cerebellum } \\
\text { vermis and } \\
\text { crossing midline }\end{array}$ \\
\hline 7 & $24 / M$ & $\begin{array}{l}\text { Progressively } \\
\text { increasing } \\
\text { headache and vomiting, } \\
\text { diminution of } \\
\text { vision, unsteadiness } \\
\text { of gait }\end{array}$ & $\begin{array}{l}\text { Left } \\
\quad \text { cerebellar }\end{array}$ & 3 months & -- & $\begin{array}{l}\text { High attenuated } \\
\text { lesion } \\
\text { surrounded } \\
\text { by low } \\
\text { attenuated } \\
\text { areas }\end{array}$ \\
\hline 8 & $14 / \mathrm{M}$ & $\begin{array}{l}\text { Squint and facial } \\
\text { asymmetry, } \\
\text { unsteadiness, } \\
\text { 6th and } 7 \text { th nerve } \\
\text { paresis, left side ataxia }\end{array}$ & Pons & 3 months & - & $\begin{array}{l}\text { PEG and } \\
\text { ventriculogram } \\
\text { suggestive of } \\
\text { positive } \\
\text { mass }\end{array}$ \\
\hline
\end{tabular}

Department of

Pathology

M C Sharma

A K Karak

K Sudha

Department of

Neuroradiology

S B Gaikwad

Department of

Neurosurgery, All

India Institute of

Medical Sciences, New

Delhi-110029, India

A K Mahapatra

V S Mehta

Correspondence to:

Dr M C Sharma,

Department of Pathology,

AIIMS, New Delhi-110029,

India.

and in revised form

Accepted 12 September 1995

.


Figure 1 T1 weighted sagittal image shows bulbous enlargement (straight arrow) of medullospinal region, which is irregular posteriorly. It is isointense with brain tissue. Partial excision of the cerebellum is seen (patient 5).

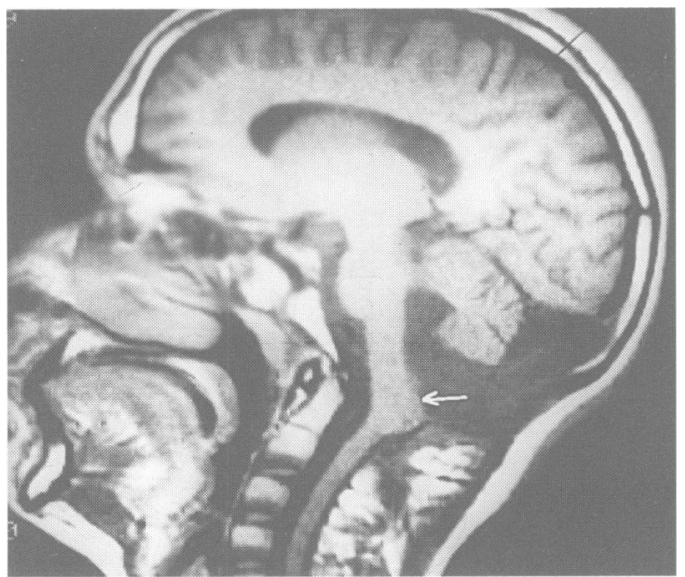

hemisphere, and two in the brain stem. The age ranged from 6 months to 45 years (average age 18.2 years). Six were male and two were female (M:F 3:1). The duration of symptoms varied from two months to five years (mean $17 \cdot 4$ months). Table 1 gives a summary of the clinical features and radiological findings.

\section{Treatment and results}

All the patients were subjected to surgery. In two cases with brain stem lesions, radical tumour excision was carried out through a suboccipital craniotomy whereas in the rest the tumours were totally excised. Peroperatively all tumours were in the parenchyma and none of them showed attachment to any of the cranial nerves. All patients showed good functional recovery except one with a brain stem lesion in whom postoperative MRI showed a residual lesion (fig 1). This patient failed to report for subsequent follow up.

\section{Pathological findings}

The entire tumour tissue for each patient was examined by light microscopy. Haematoxylin and eosin stain, Gomori silver stain for reticulin, and phosphotungstic acid haematoxylin stain for glial fibres were routinely employed. Formalin fixed paraffin embedded sections were stained by the avidin biotin peroxidase technique using monoclonal mouse antihuman glial fibrillary acidic protein (GFAP) and rabbit anticow S-100 protein (Dako Patt). The primary antibodies were used at 1:100 dilution with a one hour incubation period at room temperature.

Histological examination of the tumours showed interwoven bundles of oval or spindle shape cells containing elongated nuclei and scant eosinophilic cytoplasm. In many areas, the nuclei were aligned in a palisading arrangement and many verocay bodies were also seen (fig 2). Some of the blood vessel walls showed thickening and hyalinisation. The tumours were rich in reticulin fibres. Immunohistochemically, all were uniformly negative for GFAP but showed strong positivity for S-100 protein. In patients 1 and 7 tumour tissue was also subjected to electron microscopy, which showed closely packed oval

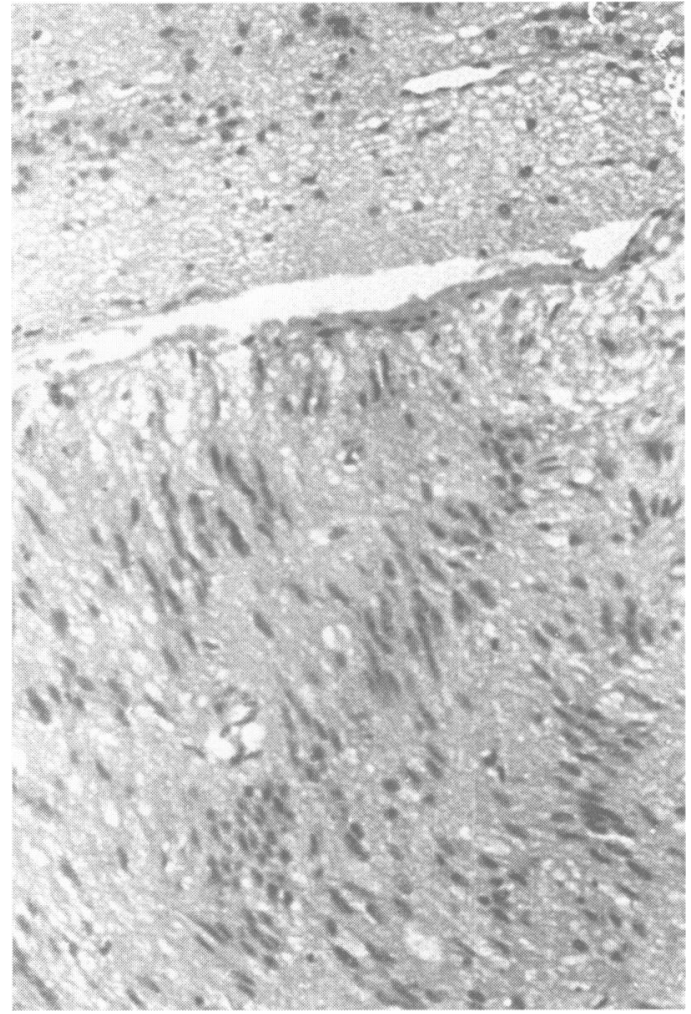

Figure 2 Light microscopy showing well marked line of cleavage between normal brain tissue and tumour tissue (patient 3; haematoxylin and eosin $\times 100$ ).

or elongated cells with many interdigitating cell processes. A basement membrane could be clearly seen around the plasma membrane. Cytoplasm of the tumour cells contained free ribosomes, some rough endoplasmic reticulum, mitochondria, and many electron dense, probably lysosomal, bodies.

\section{Discussion}

Intracranial schwannomas are not uncommon. Most of them occur in the cerebellopontine angle in relation to the vestibular nerve ${ }^{1}$ and less often in relation to other cranial nerves with the exception of the optic nerve. However, intracranial intraparenchymal schwannomas are rare. Until 1993, only 18 in the cerebral hemisphere, four in the brain stem, seven in the cerebellum, three in the sella, and one in the fourth ventricle had been reported (table 2). ${ }^{23}$ Russel and Rubinstein ${ }^{1}$ reviewed six other unpublished cases. A reported male predominance and early age of onset of symptoms are clearly evident, as in the present study. Six of our patients were male and six were under 30 years of age. The youngest patient in this series was a 6 month old infant whereas the youngest patient previously reported in the medical literature was a 6 year old child. The duration of symptoms has been reported to vary from two months to five years but can be as long as 40 years. Clinical presentation depends on the location of the tumour. The shortest duration of symptoms is reported in brainstem lesions compared with cerebral tumours. Two of our patients with cerebral tumours (1 and 3) had a short dura- 
Table 2 Reported cases of intracranial intraparenchymatous schwannomas

\begin{tabular}{|c|c|c|c|c|}
\hline Authors (year) & Age/sex & Site & Symptoms & $\begin{array}{l}\text { Duration } \\
\text { of symptoms }\end{array}$ \\
\hline Prakash et al $(1980)^{6}$ & $14 / \mathrm{M}$ & Pons & $\begin{array}{l}\text { L sided ataxia } \\
\text { 6th, 7th nerve } \\
\text { paresis }\end{array}$ & 3 months \\
\hline Solomon et al (1987) & $69 / M$ & Cervicomedullary & Paraparesis & 2 years \\
\hline $\begin{array}{l}\text { Ladouceur et al (1989) } \\
\text { Sharma and Newton }(1993)^{3}\end{array}$ & $18 \bar{M}$ & $\begin{array}{l}\text { Brainstem } \\
\text { Brainstem }\end{array}$ & $\overline{\mathrm{R}}$ sided & $\overline{2}$ years \\
\hline Komminoth et al (1977) & $15 / \mathrm{M}$ & $\begin{array}{l}\text { Vermis of } \\
\text { cerebellum }\end{array}$ & $\begin{array}{l}\text { Cerebellar } \\
\text { signs }\end{array}$ & 6 months \\
\hline Schwartz et al (1988) & $48 / M$ & L cerebellum & - & - \\
\hline Kuhn et al (1985) & $42 / F$ & $\mathbf{R}$ cerebellum & $\begin{array}{l}\text { Cerebellar } \\
\text { signs }\end{array}$ & 2 months \\
\hline Sarkar et al $(1987)^{7}$ & $24 / M$ & L cerebellum & $\begin{array}{l}\text { Cerebellar } \\
\text { signs }\end{array}$ & 3 months \\
\hline Benazza et al (1989) & $8 / \mathrm{M}$ & $\mathrm{R}$ cerebellum & $\begin{array}{l}\text { Cerebellar } \\
\text { sions }\end{array}$ & 6 months \\
\hline Trans Dinh et al (1991) & $64 / F$ & $\begin{array}{l}\text { Vermis } \\
\text { cerebellum }\end{array}$ & $\begin{array}{l}\text { Cerebellar } \\
\text { signs }\end{array}$ & 8 months \\
\hline Sharma et al (1993) ${ }^{2}$ & $73 / \mathrm{F}$ & $\begin{array}{l}\text { Vermis and } \\
\mathrm{R} \text { cerebellum }\end{array}$ & $\begin{array}{l}\text { Cerebellar } \\
\text { signs }\end{array}$ & 4 months \\
\hline Goebel et al (1979) & $25 / F$ & Intrasellar & $\begin{array}{r}\text { Grandmal } \\
\text { seizures }\end{array}$ & 12 months \\
\hline Perione et al (1984) & $39 / \mathrm{M}$ & Intrasellar & ICT & 2 years \\
\hline Wilberger (1989) & $62 / \mathrm{F}$ & Intrasellar & ICT & 6 months \\
\hline Gibson et al (1966) & $6 / \mathrm{M}$ & L temporal & Focal epilepsy & 1 year \\
\hline Scharenberg $(1971)^{4}$ & - & R occipital & Epilepsy & 7 years ${ }^{\star}$ \\
\hline New (1972) & $8 / \mathrm{M}$ & R parietal & Seizures & 2 years \\
\hline Van Rensberg et al (1975) & $21 / M$ & L temporal & Epilepsy & 7 years \\
\hline Ghatak et al (1975) & $63 / \mathrm{F}$ & $\mathrm{R}$ parietal & Seizures & 40 years \\
\hline Pialat et al (1975) & $24 / \mathrm{F}$ & $\begin{array}{l}\mathrm{R} \text { frontal } \\
\text { lobe }\end{array}$ & Epilepsy & - \\
\hline \multirow[t]{2}{*}{ Kasantikul et al (1981) } & $22 / \mathrm{M}$ & R parietal & $\begin{array}{l}\text { Neuropsychiatric } \\
\text { symptoms }\end{array}$ & 3 years \\
\hline & $21 / M$ & $\begin{array}{l}\text { L temporal } \\
\text { lobe }\end{array}$ & Seizures & 5 years \\
\hline Auer et al (1982) & $15 / \mathrm{M}$ & $\begin{array}{l}\mathrm{R} \text { frontal } \\
\text { lobe }\end{array}$ & $\begin{array}{l}\text { Subarachnoid } \\
\text { haemorrhage }\end{array}$ & Sudden \\
\hline Shalit et al (1982) & $29 / \mathrm{F}$ & L parietal & ICT & 6 months \\
\hline Rodriquez-Salazar et al (1984) & $10 / F$ & $\begin{array}{l}\text { L frontal } \\
\text { lobe }\end{array}$ & Focal epilepsy & 3 months \\
\hline Gokey et al (1984) & $16 / \mathrm{F}$ & $\begin{array}{l}\mathrm{L} \text { frontal } \\
\text { lobe }\end{array}$ & Epilepsy & 3 years \\
\hline Bruni et al $(1984)^{5}$ & $39 / \mathrm{M}$ & $\begin{array}{l}\mathrm{L} \text { frontal } \\
\text { lobe }\end{array}$ & $\begin{array}{l}\text { Grand mal } \\
\text { seizures }\end{array}$ & 2 years ${ }^{\star}$ \\
\hline Schwartz et al (1988) & - & R cerebrum & & - \\
\hline Bruner et al (1984) & $18 / \mathrm{M}$ & $\begin{array}{l}\text { R Frontal } \\
\text { lobe }\end{array}$ & Syncopal attack & $\begin{array}{r}\text { Sudden } \\
\text { onset }\end{array}$ \\
\hline Stenfanko et al (1986) & $15 / \mathrm{M}$ & $\begin{array}{l}\text { L parieto } \\
\text { occipital } \\
\text { (malignant) }\end{array}$ & ICT & 2 weeks \\
\hline $\mathrm{Ng}$ and South (1988) & $42 / \mathrm{F}$ & $\mathrm{L}$ temporal & ICT & 6 months \\
\hline Pinental et al (1988) & $8 / M$ & $\begin{array}{l}\mathrm{R} \text { lateral } \\
\text { ventricle and } \\
\text { cerebrum }\end{array}$ & ICT & 2 months \\
\hline Redekop et al (1990) & $7 / \mathrm{M}$ & 4th ventricle & ICT & 5 months \\
\hline
\end{tabular}

ॠWith associated neurofibromatosis.

For details of the references not cited in full see Sharma $e t a l^{2}$ and Sharma and Newton ${ }^{3}$

$\mathrm{R}=$ right $\mathrm{L}=$ left; $\mathrm{ICT}=$ raised intracranial tension.

tion of symptoms, of two and 2.5 months respectively. An interesting feature in this series was the location of the tumour, which was left sided in the six cases of cerebral or cerebellar involvement. Such a finding had not been reported previously in the medical literature (table 2). For the cerebral schwannomas the ratio of right to left was $1: 1$. There are only two cases out of a total of 30 reported cases of intraparenchymal schwannoma which were associated with neurofibromatosis (table 2). In the present series, however, two out of eight patients $(25 \%)$ had neurofibromatosis. Patient 1 was associated with NF-1 and patient 4 with NF-2.

Brain CT and MRI showed mass lesions of varying morphology, with non-homogenous contrast enhancement. Differential diagnoses included gliomas, meningiomas, and metastatic tumours. Microscopically the differential diagnoses considered were pilocytic astrocytoma and fibroblastic meningiomas. ${ }^{8}$ In such situations, immunohistochemistry and electron microscopy are helpful in resolving the problem as seen for patient 1. Radiologically, surgically, and microscopically the tumour resembled a meningioma but immunohistochemistry for S100 protein was strongly positive and GFAP was negative. The diagnosis was further confirmed by electron microscopy.

The treatment of choice for these tumours is total excision but this depends on the location of the tumours. ${ }^{2}$ Complete relief of clinical symptoms and signs is mostly achieved after total or radical surgical removal. In the present series, seven of our patients showed gradual but eventually complete neurological recovery without any recurrence after surgical removal of the tumour (follow up varying from one year to 10 years).

The origin of intraparenchymal schwannoma is still debated. Schwann cells are not normally found in the CNS. Hypotheses put forward to explain the origin of intraparenchymal schwannoma are: developmental abnormality resulting in the central displacement of Schwann cells during embryogenesis; tumour arising from peripheral nerve fibres containing Schwann 
cells on the vessels supplying the CNS; neoplastic involvement of aberrant intramedullary peripheral nerve fibres. Also, there are postulations that pial mesodermal cells could perhaps transform into Schwann cells, ${ }^{1}$ or Schwann cells may be formed by maturation of the primitive reticular cells, or the lesion may also arise from a defect in migration and differentiation of the neural crest cells.

The cause of the relatively high incidence in our series is not clear; it may be a chance finding or because of increased awareness; the possibility of geographic differences needs to be investigated, taking the data from other centres in India.
1 Russell DS, Rubinstein LJ. Pathology of tumours of the nervous system. 5th ed. London: Edward Arnold, 1989: 533-89.

2 Sharma RR, Gurusinghe NT, Lynch PG, et al. Intraparenchymatous schwannoma of the cerebellum. $\mathrm{Br} f$ Neurosurg 1993;7:83-90.

3 Sharma V, Newton G. Schwannoma of medulla oblongata. Br 7 Neurosurg 1993;7:427-9.

4 Scharenberg K. Neurofibromatosis (Von Recklinghausen's disease). In: Minckler J, ed. Pathology of Nervous disease). In: Minckler J, ed. Pathology of Nervous
systems. Vol 2. New York: McGraw-Hill 1971:1906-16.

5 Bruni P, Esposito S, Greco R, Oddi G. Solitary intracerebral schwannoma in Von Recklinghausen's disease. Surg Neurol 1984;22:360-4

6 Prakash B, Roy S, Tandon PN. Schwannoma of the brainstem; case report. $\mathcal{F}$ Neurosurg 1980;53:121-3.

7 Sarkar C, Mehta VS, Roy S. Intracerebellar schwannoma. Case report. $\mathcal{f}$ Neurosurg 1987;67:120-3.

8 Sobel RA, Michaud J. Microcystic meningioma of the falx cerebri with numerous palisading structures: an unusual histological pattern mimicking schwannoma Acta Neuropathologica 1985;68:256-8. 